\title{
Alman Konsolosluk Raporlarına Göre 1911-1914 Yılları Arasında Osmanlı Liman Kentlerinde Kolera
}

\section{Cholera outbreaks in Ottoman Ports Between 1911 - 1914: A Study Based on German Consular Reports}

\author{
Ahmet Asker ${ }^{1}$ (1)
}

'Doç. Dr., Mersin Üniversitesi, Fen Edebiyat Fakültesi, Mersin, Türkiye

\section{ORCID: A.A. 0000-0001-8795-5261}

Sorumlu yazar/Corresponding author: Ahmet Asker,

Mersin Üniversitesi, Fen Edebiyat Fakültesi, Tarih Bölümü, Mersin, Türkiye

E-posta/E-mail: ahmet_asker78@yahoo.de

Başvuru/Submitted: 17.08 .2020 Revizyon Talebi/Revision Requested: 23.10.2020

Son Revizyon/Last Revision Received: 13.11.2020

Kabul/Accepted: 14.11 .2020

Online Yayın/Published Online: 00.00 .0000

Atıf/Citation: Asker, Ahmet. "Alman Konsolosluk Raporlarına Göre 1911-1914 Yılları Arasında Osmanlı Liman Kentlerinde Kolera." Osmanlı Bilimi Araștırmaları 22, 1 (2021): 101-119. https://doi.org/10.26650/oba.781442

\section{öz}

Osmanlı coğrafyasına Rus hacılarla giriş yapan 1910 kolera salgını ilk önce Temmuz ayında Erzurum'da görüldükten sonra, başta liman kentleri olmak üzere civar kentlere kısa sürede yayılmıştır. Yerel Osmanlı yöneticileri, yetersiz sağlık altyapısına rağmen, karantina tedbirlerine başvurarak salgının yayılmasını engellemeye çalışmışlardır. Alınan tedbirleri yetersiz gören Hanya (Girit) halkı, inisiyatifi eline alarak bulaşıcı hastalık taşıdığı düşünülen bir geminin kentlerine yanaşmasına ve yolcu indirmesine şiddetle karşı çıkmıştır. Yöneticilerin, kimi zaman yerel halkın paniğe kapılarak kaotik bir ortamın doğmasını önlemek amacıyla, kimi zaman da deniz ticaret ve posta trafiğinin aksamasından kaynaklı maddi kayıpların önüne geçmek için, salgın haberleri ile ilgili gerçekleri halktan gizlemeye çalıştıkları olmuştur. Bu makalede kolera salgınının Hayfa, Beyrut, Yafa, Hanya, Samsun, Trabzon, İzmir, Çanakkale, Selanik gibi Osmanlı liman kentleri ile Adana, Osmaniye, Halep, Tiberya, Şam gibi civar kentlerde yarattığı panik atmosfer ve sonrasında yaşananlar 19111914 arasında kaleme alınmış olan Alman konsolosluk raporlarına yansıdığı kadarıyla konu edilmiştir. Kolera karşısında yerel düzeyde yaşanan olaylar genel tablo hakkında fikir vermesi açısından önemlidir.

Anahtar sözcükler: Salgın, kolera, veba, limanlar, karantina, Orta-Doğu, Osmanlı Devleti, Türkiye

\section{ABSTRACT}

The 1910 cholera epidemic, brought to the Ottoman Empire by Russian pilgrims, first appeared in Erzurum in July 1910. It then spread to other Ottoman cities, particularly those with harbors. Despite the cities' inadequate health infrastructure, local administrators resorted to quarantine measures to stem the spread of the epidemic. Local people of Hania (Crete) considered these measures insufficient and strongly opposed the docking of a ship that was thought to carry infectious disease, as well as the disembarkation of its passengers. Occasionally, administrators attempted to conceal the realities of the epidemic from the public to forestall financial loss from the disruption of maritime trade and postal traffic and to prevent panic and chaos from 
breaking out. This article examines the atmosphere of panic that the 1910 cholera epidemic created in the Ottoman port cities of Haifa, Beirut, Jaffa, Chania, Samsun, Trabzon, Izmir, Çanakkale, and Thessaloniki, as well as the inland cities of Adana, Osmaniye, Aleppo, Tiberia, and Damascus. It also examines some events that followed the epidemic as reflected in the consular reports of 1911-1914. Local incidents occurring during an epidemic may provide important clues toward understanding and evaluating the overall picture of the era and the area.

Keywords: Epidemic, cholera, plague, harbor cities, quarantine, Middle-East, Ottoman Empire, Turkey 


\section{Giriş}

İnsanlık tarihinde derin izler bırakan salgın hastalıklar uzun kervan yolları boyunca veya bir limandan diğerine hızla yayılmış, görüldüğü yerde maddi-manevi büyük zararlara sebep olmuştur. İnsanları birçok kez hazırlıksız yakalayarak ani ve kitlesel ölümlere yol açan bazı salgınların etkileri o kadar feci olmuştur ki, aradan yüzyıllar geçmesine rağmen adından söz ettirebilmiştir. Orta Çağ'da Avrupa'yı kasıp kavuran, Kara Ölüm adıyla anılan veba salgını en bilinen örneklerdendir ve çeşitli türleri ile yirminci yüzyılın ilk yarısına kadar can almaya devam etmiştir. ${ }^{1}$ İnsanlık, tıp ilminin geliştiği modern zamanlara kadar karşılaştı̆̆ 1 çeşitli salgın hastalıklarda büyük kayıplar vermiş olsa da yaşama tutunarak türünü devam ettirmeyi başarmıştır. Günümüzün modern tıbbi imkânları dahi, bulaşıcı hastalıklara sebep olan virüs ve bakterilerin tehdidini tamamen yok edememiştir.

Günümüzden yaklaşık bir asır önce, geniş bir coğrafyayı etkisi altına alan başka bir virüs salgını, milyonlarca insanın ölümüne sebep olan İspanyol Gribidir. Ancak insanlığa yönelik salgın tehdidi sadece virüslerden gelmemiştir. Bakteri salgınları da ölümcül hastalıklara sebebiyet vererek insanlar arasında benzer endişe ve kayıplara yol açmıştır. En korkulan bulaşıcı hastalıklardan biri, Vibrio cholerea bakterisinin yol açtığı koleradır. Bombay'dan Güney Çin'e kadar geniş bir sahada sık rastlanan kolera, 1800'lerin başında Hindistan'ın Ganj Nehri kıyılarında, özellikle Bengal Eyaleti'nde görülen endemik bir bakteri türü iken, on dokuzuncu yüzyılın ilk çeyreğinden başlayarak, epidemi ve pandemilere sebep olmuştur. Birçok bölgesel salgının yanı sıra, dünya çapında 6 kolera pandemisi (1817-1823, 1829-1851, 18521859, 1863-1879, 1881-1896, 1899-1923) kaydedilmiştir. ${ }^{2}$ Yirminci yüzyılın başlarına kadar yüzbinlerce insanın ölümüne yol açan koleranın yayılmasında on dokuzuncu yüzyılda ulaşım teknolojilerinde kaydedilen gelişmelerin büyük etkisi vardır. Uzak yerlere ulaşımı mümkün kılan trenler ile kıtalar arası seyahat imkânı tanıyan buharlı gemiler, hastalığın pandemiye dönüşmesine aracılık etmiştir. Dolayısıyla tren istasyonları, limanlar ve kervan yolları gibi insanların kalabalık ve hareket halinde olduğu yerler, hastalığın yayılma noktaları olmuştur. Hastalık, Batı'ya denizden ve karadan olmak üzere iki koldan yayılmıştır. Karayolundan, Hindistan'ın kuzeyi, Afganistan, İran, Orta-Asya, Rusya güzergâhını; denizyolundan ise Basra Körfezi, Kızıldeniz kıyıları, Mısır ve Akdeniz güzergâhını takip etmiştir. Kolera salgınının bazen her iki yoldan aynı anda dünyaya yayıldığı görülmüştür. On dokuzuncu yüzyılın başlarından itibaren insanlığı tehdit eden bu hastalık karşısında devletler, yerel sağlık teşkilatlarını kurmak suretiyle önlemler almaya başlamış ve milletlerarası bir sağlık organizasyonuna gidilmiştir. ${ }^{3}$

1 Hikmet Özdemir, Salgın Hastalkklardan Ölümler 1914-1918 (Ankara: Türk Tarih Kurumu Yayınları, 2005), 3-31; Tolga Karaimamoğlu, "Kara Ölüm Veba Salgını ve Ortaçağ İngiltere'sine Etkileri," Akademik Sosyal Araştırmalar Dergisi 4, 37 (2016): 591-610.

2 Dhiman Barua, "History of Cholera," Cholera, yay. haz. Dhiman Barua and William B. Greenough III (New York: Plenum Medical Book Company, 1992) içinde, 2-15.

3 Gülden Sarıyıldız, Hicaz Karantina Teşkilatı (Ankara: Türk Tarih Kurumu, 1996), 1-4. 
Coğrafi konumuyla Asya ve Avrupa arasında bir geçiş bölgesi olan Osmanlı İmparatorluğu, salgınların yıkıcı etkisine maruz kalmış, kolera salgınları birçok kez Osmanlı kentlerini de etkisi altına almıştır. ${ }^{4}$ Salgının ilk kez İstanbul'a gelişi, zamanın ulaşım olanakları düşünüldüğünde, yavaş olmuştur. 1831'de İstanbul'da görülen kolera, 1832'de imparatorluğun diğer kentlerine yayılmıştır. ${ }^{5}$ Osmanlıda ilk ortaya çıktığı andan itibaren, I. Dünya Savaşı'nın (1914-1918) sonuna kadar birkaç yıl arayla, neredeyse kesintisiz devam ettiği izlenen kolera salgınlarında kayıt altına alınan ölüm oranları -- rakamlarda bir kesinlikten söz edilemeyecek olsa dahi-- hastalık karşısındaki çaresizliğin bir göstergesidir. 1830-1831'deki kolera salgını sadece İstanbul'da 6.000 civarında insanın ölümüne sebep olmuştur. İkinci salgının, 25 Ekim 1847'den Kasım 1849'a kadar İstanbul'da 4.275 insanın canına mal olduğu kaydedilmiştir. 1865 yazında İstanbul'a yeniden uğrayan kolera salgınında ise yaklaşık 30.000 İstanbullunun hayatını kaybettiği söylenmektedir. ${ }^{6} 1870$ 'lerin başındaki salgında dört ayda İstanbul'da 4.000 kişi ölmüştür. ${ }^{7} 1$ Mayıs 1894'teki kayıtlar 1.588 insanın ölümünü haber vermektedir. ${ }^{8}$ Y irminci yüzyılın ilk çeyreğinde Osmanlı coğrafyasına yeniden, bu sefer Rus hacılarıyla giriş yaptığı ileri sürülen kolera 1910'da şiddetlenerek, I. Dünya Savaşı (1914-1918) sonuna kadar birçok insanın canını almaya devam etmiştir. '̇ İstanbul'da; 1911'de 1.583, Balkan savaşları sırasında ise (1912-1913) 1.277 insanın daha kolera sebebiyle hayatını kaybettiği kaydedilmiştir. ${ }^{10}$ Savaş sırasında, zamanın ilkel koşullarında yurtlarından kovulduğu için yollara düşen insanlar arasında kolera salgınından ölenlerin daha yüksek olabileceği beklenirken, oranlarda az da olsa bir düşüş gözlenmesinde, sıkı karantina tedbirlerinin yanı sıra, 1902'de geniş ölçüde Japonya'da uygulanan ve Osmanlı'da ilk kez Balkan savaşları sırasında kullanılmaya başlanan ${ }^{11}$ kolera aşısının etkili olduğu düşünülebilir. Ayrıca, araştırılmayan, sebebi belli olmayan veya belli olup da yazıya dökülmeyen ölümlerin olduğu da hesaba katılmalıdır. Ancak toplama bakıldığında azımsanmayacak bir sayıya ulaş1lır. Osmanlı kentlerinden toplanan 1911 yılı verilerine göre, koleraya yakalanan 18.876 kişiden 12.143 'ü $\left(\%\right.$ 64,3) hayatını kaybetmiştir. ${ }^{12}$

Koleranın görülmesinden sonra Osmanlı Devleti de sağlık önlemleri almaya başlamıştır. 1823 yılından itibaren sönmüş gibi görünen koleranın Rusya'da yeniden canlanması üzerine, Fransa sefaret tercümanı Osmanlı riyaset makamına giderek Rusya'da şiddetle

4 Özdemir, Salgin Hastallklardan Ölümler, 32-33.

5 Nuran Yıldırım, "Tanzimat'tan Cumhuriyet'e Koruyucu Sağlık Uygulamaları," Tanzimat tan Cumhuriyet'e Türkiye Ansiklopedisi, Cilt 5 (İstanbul: İletişim Yayınları, 1985), 1326.

6 Nuran Yıldırım, “Kolera ve İstanbul Suları,” Toplumsal Tarih Sayı 145 (Ocak 2006): 4.

7 Nuran Yıldırım, "Osmanlı Coğrafyasında Karantina Uygulamaları. Karantina İstemezük!," Toplumsal Tarih Say1 150 (Haziran 2006): 25.

8 Yıldırım, "Kolera ve İstanbul...," 4.

9 Yildırım, "Tanzimat'tan Cumhuriyet'e Koruyucu...,"1326.

10 Yıldırım, "Kolera ve İstanbul...," 4.

11 Y1ldırım, "Tanzimat'tan Cumhuriyet'e Koruyucu...," 1327.

12 Özdemir, Salgın Hastalıklardan Ölümler, 37. Bu verilerin kesin ölüm oranlarını yansıtmadı̆̆ı, dönemin koşulları düşünüldüğünde raporlara yansıyamayan vakaların da olduğu unutulmamalıdır. 
hüküm süren kolera salgınını haber vermiş, aynı haberi alan diğer devletlerin tercümanları Rusya'dan İstanbul'a gelen Rus gemilerine karantina uygulanmasını istemişlerdir. Bunun üzerine Osmanlı hükümeti, bir an önce karantina işlerinin müzakere edilmesi ve ihtiyaçların belirlenerek karantinaya başlanması kararını almıştır. Böylece, Osmanlı İmparatorluğu'nun kolera ile tanıştığ 1831 yılında, İstanbul Boğazı'nda ilk ciddi karantina uygulanmıştır. ${ }^{13} 1838$ Mayıs ayında II. Mahmut tarafından kadı ve naiblere gönderilen bir emirle Osmanlı ülkesinde karantina usulünün uygulanmaya başlandığı ve İstanbul'un sıhhi kordon altına alındığı bildirilmiştir. ${ }^{14}$ Birkaç ay sonra ise, 22 Temmuz 1838'de Avusturyalı Dr. Minas, karantina baş direktörü olarak atanmıştır. Dr. Minas’ın önerisiyle karantina kurallarını belirlemek üzere Sıhhiye Meclisi (Conseil Supérieur de Santé) kurulmuştur. ${ }^{15}$ Dr. Minas başkanlığında 10 Haziran 1839'da ilk kez toplanan Sıhhiye Meclisi, İstanbul'da başlatılacak olan karantina uygulamasının kordon usulüyle yürütülmesini kararlaştırılmıştır. Toplantıda kabul edilen Deniz Vilayetleri İçin İdari Nizamname, 27 Mart 1840’tan itibaren Osmanlı İmparatorluğu'nun bütün limanlarında geçerli kılınmıştır. Söz konusu nizamnameye göre İstanbul'a gelen her gemi bir sağlık kontrol belgesine (sağlık patentası) sahip olacak ve bunu kontrol memuruna uzun bir sopayla teslim edecektir. Karantina bekleme süresi, şüpheli patentası olan gemiler için 10, bulaşık patentası olan gemiler için ise 15 gün olarak belirlenmiştir. Eşya ve yolcular, İstanbul'da Kuleli Karantinahanesine yerleştirilmiştir. Bundan böyle ister Akdeniz'den ister Karadeniz'den gelmiş olsun her gemi sağlık bakımından sorgulanacak ve kaptan, geminin sağlık durumu hakkında bilgi paylaşacaktır. ${ }^{16}$

Erzurum'a 15 Temmuz 1910'da Rusya'dan kara yolu ile ulaşan kolera, liman kentlerinde daha yoğun olmak üzere, bütün Anadolu ve Rumeli'ye yayılmıştır. ${ }^{17}$ Yerleşim yerlerinde vakaların ilk kayıt altına alındığı tarihler, salgının Osmanlı coğrafyasında yayılma hızını göstermektedir: 29 Ağustos: Van; 31 Ağustos: Elâzığ, 1 Eylül: İstanbul, 2 Eylül: Zonguldak, 16 Eylül: Trabzon, 18 Eylül: Samsun, 17 Ekim: Divriği, 21 Ekim: Edirne, 25 Ekim: Aydın, 3 Kasım: İzmit, 6 Kasım: Amasya, Merzifon, Zile, Tokat, Sivas, 7 Kasım: Bursa, 16 Kasım: Selanik, 17 Kasım: Bandırma, 18 Kasım: Ankara, 23 Kasım: Manastır, Akşehir, 24 Kasım: Çatalca, Büyükçekmece, 25 Kasım: Yalvaç, 28 Kasım: Sinop ve Boyabat, 7 Aralık: Cizre. ${ }^{18}$

Birinci Dünya Savaşı öncesinde Osmanlı hükümeti, yurtlarından sürgün edilen muhacirler arasında ve Balkan savaşlarının yıkıcı etkisi altında zirve yapan bulaşıcı hastalıklarla mücadele

13 Sarıyıldız, Hicaz Karantina Teşkilatı, 5.

14 Yıldırım, “Tanzimat'tan Cumhuriyet'e Koruyucu...” 1323.

15 Yıldırım, "Osmanlı Coğrafyasında Karantina...," 18-19.

16 Nuran Yıldırım, “İstanbul Boğazı'nda Karantina Uygulamaları,” Yeni Deniz Mecmuast (1 Mart 2016 ): 46.

17 Özdemir, Salgın Hastalıklardan Ölümler, 35; Nuran Yıldırım'ın makalesinde koleranın Osmanlı’ya girişiyle ilgili geniş bir tarih aralığı verilmektedir: "1907-1915'te memleketimize Rus hac1larıyla gelen kolera...", Y1ldırım, "Tanzimat'tan Cumhuriyet'e koruyucu..." 1326.

18 Özdemir, Salgın Hastalıklardan Ölümler, 35. 
etmek için önemli adımlar atmıştır. ${ }^{19}$ Birinci Dünya Savaşı boyunca da devam eden salgın hastalıklar ${ }^{20}$ ile mücadele, yirminci yüzyılın başından itibaren, savaşlar, göç ve mübadelelerle yoğun nüfus kaybı yaşayan genç Türkiye Cumhuriyeti’nin öncelikli gündemlerinden biri olmuştur. ${ }^{21} \mathrm{Bu}$ yazıda, Osmanlı coğrafyasında 1910 yazında görülen kolera salgınının; Hayfa, Beyrut, Yafa, Hanya, Samsun, Trabzon, İzmir, Çanakkale, Selanik gibi Osmanlı liman kentleri ile limanlarla bağlantılı Adana, Osmaniye, Halep, Tiberya, Şam gibi civar illerde yarattığı panik atmosfer ve sonrasında yaşanan süreçler, Alman arşiv belgelerinde yer alan konsolosluk raporlarına yansıdığı kadarıyla konu edilmiştir. Alman Dışişleri Bakanlığı Politik Arşivi'nde (PAAA) bulunan Epidemische Krankheiten 1911-1914 (Epidemik Hastalıklar 1911-1914) başlıklı dosya bu yazının ana kaynağını oluşturmaktadır. Söz konusu dosyanın 1911-1914 tarih aralığında, farklı konsolosluklarda kaleme alınmış belgeleri içermesi, yazının kronolojik ve mekânsal sınırlarını belirlemiştir. Alman konsolosların, görev alanlarında yaşanan hastalıklara ilişkin tuttukları kayıtlardan aktardığımız bilgilerin, kolera salgınının kentlerde yarattığı etkiyi ve bunun toplumsal hayata yansımalarını anlamamıza yardımcı olması beklenmektedir.

\section{Osmanlı Kentlerinde Kolera}

Hastalığın yayılmasına en elverişli yerler, farklı bölgelerden gelen yolcuların geçiş noktası olan limanlar ve demiryolu istasyonları ile Yahudi, Müslüman ve Hristiyanların kutsal mekânları gibi toplu buluşma noktalarıdır. 1910'da görülen kolera hastalığı, hem demiryolları ve limanların bulunduğu geçiş güzergâhlarına, hem de kutsal mekânlara ${ }^{22}$ ev sahipliği yapan Osmanlı coğrafyasında etkili olmuştur. Özellikle uluslararası ticaret ve insan trafiğginin hareketli noktaları olan Osmanlı liman kentleri kolera salgınının üsleri haline gelmiştir. Dönemin başlıca liman kentleri olan İstanbul, İzmir, Hanya, Hayfa, Yafa, Samsun, Trabzon, Selanik ile civar kentler hastalığın en çok görüldüğü yerlerin başında gelmektedir. Salgın ile mücadele kapsamında sıkı tedbirlere başvurularak limanlarda karantina istasyonları kurulmuştur. Gemi ve kara yolu ile seyahat eden yolculara günlerce karantina tedbirleri uygulanmasına rağmen yıllarca salgının önüne geçilememiştir. Kolera, kısa sürede sebep olduğu hızlı ölümden dolayı veba ile beraber dönemin en korkulan salgın hastalıklarından biri olmuştur. İnsanlar arasında hızla bulaşarak kitlesel ölümlere yol açan hastalık, görüldüğü

19 Melanie Schulze-Tanielian, Disease and Public Health (Ottoman Empire/Middle East), erişim 9 Haziran2020, https://encyclopedia.1914-1918-online.net/article/disease_and_public_health_ottoman_empiremiddle_east, Salgın hastalıklarla mücadelede Mersin örneği için bkz. Emrah Yıldız, “Arşiv Belgelēi Işı̆̆ında Mersin'de Salgın Hastalıklar (19. Yüzyıl)," Mersin Üniversitesi Akdeniz Kent Araştırmaları Merkezi, yay. haz. Tülin Selvi Ünlü ve Züheyla Sara Belge (Mersin: Mersin Üniversitesi, 2013) içinde, 81-91.

20 Ramazan Çalık ve Muzaffer Tepekaya, "Birinci Dünya Savaşı Esnasında Anadolu'daki Salgın Hastalıklar ve Ermeniler,” Selçuk Üniversitesi Sosyal Bilimler Enstitüsü Dergisi Sayı 16 (2006): 210.

21 Fahriye Emgili, "Cumhuriyet Dönemi Nüfus Siyasetinde Sitma Mücadelesinin Önemi," The Journal of Academic Social Science Studies Say1 50 (2016): 297-318.

22 Sinan Kuneralp, “Osmanlı Yönetimindeki (1831-1911) Hicaz’da Hac ve Kolera,” çev. Münir Atalar, Ankara Üniversitesi Osmanlı Tarihi Araştırma ve Uygulama Merkezi Dergisi Say1 7 (1996): 497-511. 
yerlerde panik ve korkuya yol açmış, yer yer sonlandığı sanılsa da yıllarca yeni kolera vakaları rapor edilmeye devam etmiştir.

Hastalığın toplumsal etkilerini yansıtan Alman konsolosluk raporları, koleranın en çok, insan ve ticaret trafiğinin yoğun olduğu liman kentlerinden başlayarak Osmanlı coğrafyasının ücra yerlerine kadar yayıldığını göstermektedir. Gördüklerini kaleme alan dönemin tanıkları ise koleranın insanlarda yarattığı dehşeti -- konsolosluk raporlarının soğukkanlı anlatımına kıyasla -- daha canlı yansıtmıştır. O dönemde Samsun'da bulunan İngiliz seyyah William John Childs (1869-1933) bunlardan biridir. Kolera, 1911 Mayıs ayında Samsun' da görüldüğü sirada $^{23}$ Childs, Anadolu'yu kuzey-güney yönünde yürüyerek kat etmek üzere Samsun'a gelmiştir. Childs, yolculuğunun başında ani ve hızlı ölümlere sebep olan koleranın yol açtığı toplumsal kriz halini birebir yaşamış ve bu olayı yayınladığı anı kitabında paylaşmıştır:

Kolera Samsun'a yaz başında musallat oldu. Ansızın geldi; insanlar yolun ortasında vurulmuşçasına acıyla yerlere yuvarlandılar ve o sırada başlarına ne geldiğini bilemediler. Salgın şiddetle arttı; geçit karantinayla kesildiğinden Bağdat Yolu'nda trafik durdu; gemiler limana gelmekten kaçındılar, kaçmanın bir yolu yoktu; çünkü köylüler dağ köylerine kaçan kentlileri ateş açarak kovuyorlardı. Köylüler, başka yerler gibi Samsun'un da kendi kolerasına kendisinin katlanması gerektiğini söylüyorlardı. Bu olağanüstü koşullarda ticaret alt üst olunca, Samsun'daki iş çevreleri -başka bir değişle yabancılar, Rumlar ve Ermeniler- hastalıkla savaşmak zorunda kaldılar. Bu ülkede Hıristiyanlar koleradan Müslümanlardan çok daha fazla korkarlar. Ancak biri hastalığa karşı elinden geleni yaparken, öteki Allah'ın takdirine ve Muhammed'in koruyuculuğuna sı̆̆ınırsa hiçbir sonuç alınamaz. Bu nedenle, Samsun'daki ticaret erbabı kenti kurtarmak üzere alınacak tüm önlemler için yetkililerden onay ve ayaktakımının bağnaz ayaklanmasına karşı askeri destek sözü aldı. Ayrıca, tedbirlerin maliyetini üstlendiler ve büyük bir bağış yaptılar. Ön hazırlıklar ivedilikle yerine getirildi ve komite işe koyuldu; hastalığın görüldüğü her ev içinde oturanların giysileri ve eşyaları ile birlikte ateşe verildi. Yok edilen mal mülk için tazminat toplanan paralardan karşılandı. Bu ve başka önlemlerle hastalığın kökü kazındı ve Samsun salgından etkilenen öteki bölgelerden daha az zarar gördü. Yine de bu parlak örneği izleyen başka bir kent olmadı. Salgının öteki yerlerde, daracık pis ara sokaklarıyla ve temizliği kuşkulu suyuyla nasıl ilerlediği, Samsun'dan çok daha küçük, nüfusu tamamen Müslüman olmasa da bağnaz Müslümanlardan oluşan Çorum örneğinde görülebilir. Kente kolera başladığında, halk bunu Allah'ın takdiri olarak tevekkülle karşıladı; hastalığa kurban gidenleri yıkadılar, dualarla defnetmeye hazırladılar ve ailesi ölünün çevresinde toplanarak yas tuttu. Kısa sürede binden fazla kişi öldü; felaket ancak salgının şiddeti kesilince son buldu. ${ }^{24}$

23 İ. Arda Odabaşı, "Selanik 1910-1911: Kolera Salgınları, Kahraman Bir Doktor, Yahudi İşçilerin İsyanı ve Serseri Gazeteciler," Toplumsal Tarih Sayı 296 (2018): 57.

24 William John Childs, Yürüyerek Anadolu, Samsun-Halep, 1911-1912, çev. Füsun Tayanç ve Tunç Tayanç (İstanbul: Kitap Yayınevi, 2017), 27. 
Samsun'daki panik, endişe ve çaresizlik hali, hastalığın görüldüğü diğer Osmanlı kentlerinde benzer şekilde yaşanmıştır. Söz konusu kentlerde görev yapan Alman konsolosların kaleme aldıkları raporlar, kolera karşısında yaşananları daha sade bir dille anlatır:

\section{Yafa'da Kolera}

1911 Ağustos sonunda bir Rus yolcu gemisinin salgını şehre getirdiği yönündeki haberlerin yayılması Yafa' da huzursuzluk yaratır. 31 Ağustos öğleden sonra saat iki sularında Hayfa' dan gelen Lazaref adlı Rus gemisi Yafa limanına yanaşmıştır. Suriye'nin iç bölgelerinden Hayfa limanına gelerek Port Said limanına (Mısır) gitmek üzere bilet kestiren 60 yaşlarında Arap bir yolcu, hastalık belirtileri göstermesi üzerine saat 5 sularında kaptan tarafindan Yafa'da gemiden indirilir. Karaya adım attığı sırada kusan hasta etraftakiler tarafından görülür ve bir anda onun koleraya yakalandığı söylentileri yayılır. Adam ertesi gün şehrin kuzeyinde bulunan karantina bölgesine nakledilir ancak 2 saat süren yolculuk sonrasında hayatını kaybeder. Bu olay üzerine, gemi ile irtibata geçen kişiler arasından tespit edilebilenler hemen karantinaya alınır. Süreç bir telgraf ile Kudüs'e rapor edilir ve trenle Kudüs'e varan Lazaref gemisi yolcularının dezenfekte edilmesi sağlanır. Laboratuvar araştırmaları sonucunda doktorlar bakterinin niteliği hakkında görüş birliğine varamazlar. Kudüs’e gönderilen dışkı örneklerini inceleyen İngiliz ve Rus doktorlar hastalığın kolera olmadığı, karantina bölgesinde görev yapan devlet doktorları ise (doktorlardan biri Alman vatandaşı Dr. Saad ${ }^{25}$ ) kolera olduğu yönünde birbirinden farklı içeriğe sahip raporlar kaleme alırlar. ${ }^{26}$

İngiliz ve Rus doktorların aksi yöndeki teşhisine rağmen, Yafa halkı yayılan söylentiler sonrasında hasta yolcunun ölümüne yol açan hastalığın kolera olduğuna kanaat getirir. Yerel bir Arap-Filistin gazetesi, ölen yolcunun koleraya yakalanmış olduğu yönünde bir haber yayınlar. Haber bir anda insanları, düzenli sefer yapan Rus gemisini boykot etmeye kışkırtan Anti-Rus bir atmosfer yaratır. Gazetede yer alan yazıda Lazaref adlı geminin kaptanının, hastalık taşıyan yolcuları gizlice gemiden karaya götürmeleri için kayıkçılara 2 Sterlin rüşvet verdiği iddiasına yer verilir. Böylece Rus kaptan öfkenin hedefi haline gelir. Bu haber üzerine Rusya konsolosu, haberlerin asılsız olduğunu açıklar. Açıklamasında, dışkı örneklerini inceleyen Kudüs’teki İngiliz ve Rus doktorların, ölen yolcunun kolera olmadığını rapor ettiklerini hatırlatır. Lazaref' in kaptanı ise iddiaların gerçeği yansıtmadığını, kendisi hakkındaki asılsız iddialara yer veren gazetenin editöründen şikâyetçi olduğunu, Türk yasalarına göre gerekli cezai işlemlerin uygulanması için kaymakamlığa başvurduğunu bildirir. Ruh sağlı̆̆ının yerinde olmadığı gerekçesiyle yolcuyu gemiden indirdiğini ifade

25 Dr. Lamec Saad (1852-1931), Osmanlı Devleti'nde 30 y1l doktorluk hizmetinde bulunmuş Alman doktordur. Çok zorlu geçtiğini ifade ettiği görev süresi zarfında bulaşıcı hastalıklarla mücadelesini de konu alan ve başlığını "Türkiye'de 16 yıllık karantina doktorluğu” şeklinde Türkçe’ye çevirebileceğimiz kitabını 1913 yılında Berlin'de yayınlanmıştır: Lamec Saad, Sechzehn Jahre als Quarantäneartz in der Türkei (Berlin: Dietrich Reimer (Ernst Vohsen), 1913).

26 Bericht von Dr. Brode, J.Nr.1166, Konstantinopel-408, Jaffa, den 8 September 1911. 
eder. Buna göre yolcunun, gemide tuhaf hareketler yaparak, psikolojik rahatsızlığı olduğu şüphesini uyandırması sonrasında, diğer yolcuların huzurunu kaçırmaması için kaptan onu gemiden indirmiştir. Nihayet 4 Eylül'de, kaymakamlıkla ve İstanbul'la yapılan yazışmalar sonrasında hastalığın kolera olmadığı sonucuna varılır ve 6 Eylül'de İstanbul'dan gelen bir emirle karantina doktorlarından bu yönde yeni bir rapor hazırlamaları istenir. Yeni raporda; Ramazan ayında oruç tutmuş olan yaşlı yolcunun, mide bulantısı ile kusmasının sebebinin, dalgalı denizde geminin çalkalanması olduğu yazılır. Bitkin düşen yolcu karaya çıkar çıkmaz aç midesiyle sigara içmiş, engebeli arazide 2 saatlik yorucu bir yolculuğu kaldıramayarak hayatını kaybetmiştir. Ancak bu yeni rapor, yerel halkın endişesini gidermeye yetmez. Kolera söylentilerinin yarattığı panik sonrasında Rus gemisine yönelik sıkı karantina tedbirleri uygulanır. Rus konsolos, 5 Eylül'de Lazaref gemisinin güvertesinde, Yafa'ya inmek isteyen yolcuların, güvertede oluşturulan sağlık kontrol noktasından geçirileceğini açıklar. ${ }^{27}$

Alman konsolos Dr. Brode yukarıdaki bütün açıklamalara rağmen ikna olmamıştır. Brode raporunda; "yolcu madem koleraya yakalanmış değil de psikolojik hastaydı, kaptan neden Yafa'daki bir sağllk kuruluşunu bilgilendirmeden onu gemiden indirdi?" sorusunu sorar. Ayrıca Rus konsolosun kendisine, Kudüs'teki İngiliz konsolosunun dostu olduğunu ve bu olayın kolera olmadığı iddiasının doğrulanmasında kendisinden güçlü bir destek gördüğünü ifade etmiş olması Brode'nin şüphelerini arttırmıştır. Zira dışkı örneklerini laboratuvarda inceleyerek bakterinin kolera olmadığı yönünde raporları kaleme alan iki doktordan biri Rus, diğeri İngiliz'dir. İngiltere'nin denizlerdeki yolcu ve posta trafiğini aksatacak söylentilerden zarar görecek olması, örtbas şüphesini arttıran diğer bir faktördür. Türk hükümet yetkilileri, bu olay karşısında, hasta yolcuları gemiden karaya taşıyan kayıkçılara cezai işlem uygular. Ayrıca Rus hükümetinden, dezenfeksiyon işlemleri ve karantina tedbirlerinin masraflarını karşılaması talebinde bulunur. Türk yetkililerin, olayın duyulmasından hemen sonra sıkı karantina önlemleri almasına rağmen, Mısır hükümet yetkilileri hiçbir karantina önlemi almadan Rus Lazaref gemisinin Port Said limanına yanaşarak yolcuları indirmesine ve limandan ayrılmasına izin vermiştir. Dr. Brode, Türk yetkililerin hastalık şüphesi karşısındaki bu ciddi tavrını takdir ettiğini ifade etmiştir. ${ }^{28}$

Kasım sonunda, Filistin bölgesinde uygulanan sıkı karantina tedbirlerinin yumuşatılması umulur. En son kolera teşhisi konulan 3 hastadan birinin 26 Kasım'da öldüğü, ancak diğer ikisinin iyileşmekte olduğu rapor edilir. Bu sevindirici durum, salgının sonuna gelindiği yönündeki umutları arttırır. ${ }^{29}$ Ancak umutlanmak için henüz çok erkendir. Ayrıca Yafa'da korkulan tek salgın kolera değildir. Konsolos Brode, birkaç gün sonraki raporunda İstanbul Alman büyükelçiliğine, Yafa'nın yaklaşık 10 km kuzeyinde bulunan Yahudiye köyünde Sığır

27 Bericht von Dr. Brode, J.Nr.1166, Konstantinopel-408, Jaffa, den 8 September 1911.

28 Bericht von Dr. Brode, J.Nr.1166, Konstantinopel-408, Jaffa, den 8 September 1911.

29 Bericht von Dr. Brode, J.Nr.1570, Konstantinopel-408, Jaffa, den 29 November 1911. 


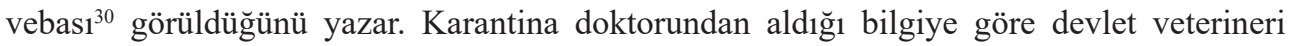
elindeki bütün serum ve aşıları toplayarak Alman kolonisi Wilhelma'daki köylülere teslim etmiştir. ${ }^{31}$ Brode'nin bu raporu ayrıntı içermez, ancak korkuya yol açan salgın hastalıkların sadece insanlarla sınırlı olmadığını göstermesi açısından önemlidir.

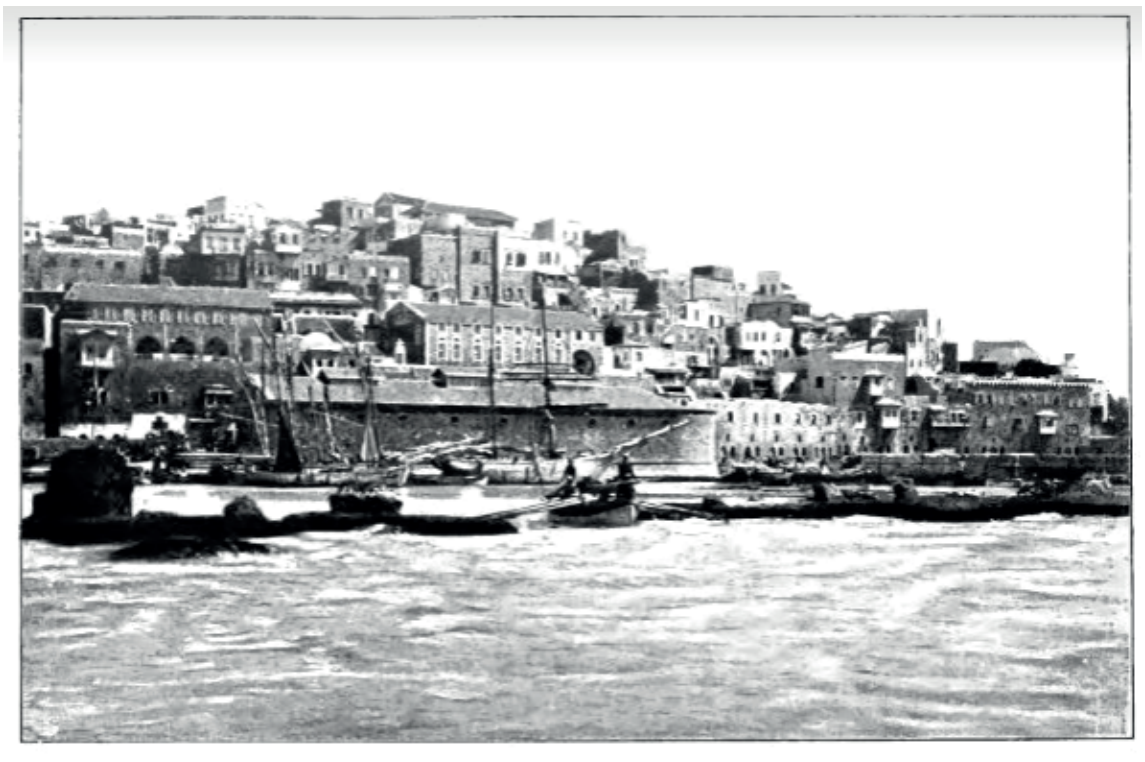

IAFA.

Yirminci yüzyılın başında Yafa'dan bir görüntü32

\section{Hayfa'da Kolera}

Yafa'nın yaklaşık $100 \mathrm{~km}$ kuzeyinde yer alan Hayfa'da da aynı dönemde kolera korkusu hüküm sürmüştür. Krüger, İstanbul Alman büyükelçiliğinden, Avrupa’ya gidecek postaların dezenfeksiyonu için Hicaz demiryolu üzerinden acil dezenfeksiyon malzemesi

30 Sığır vebası (Rinderpest, Malkıran ya da Çor), son derece ölümcül ve bulaşıcı olan viral bir hayvan hastalığıdır. Hayvanlarda sindirim kanalı mukozasında şiddetli ülseratif ve hemorajik lezyonlarla karakterizedir. Hastalık genel durgunluk, bitkinlik, halsizlik, iştahsızlık, yüksek ateş, gözyaşı, burun ve salya akıntısı gibi belirtilerle birden ortaya çıkar. 3 gün içinde bütün sindirim kanalında şiddetli nekrotik ve ülserli yangı şekillenir. 4. günde başlayan çok şiddetli ishal sonucu hayvan birkaç gün içinde ölüme sürüklenir. Ahırdaki hayvanların tümü hastalanır ve hemen hemen hepsi öldüğü için sığırların en öldürücü ve en bulaşıcı hastalığıdır. 8 Ağustos 2011'de Birleşmiş Milletlerde yapılan törende insanlardaki çiçek hastalığından sonra bu hastalığın dünyadan silinen ikinci hastalık olduğu ilan edilmiştir.

31 Bericht von Dr. Brode, J.Nr.1171, PAAA, Konstantinopel-408, Jaffa, den 11 September 1911.

32 Saad, Sechzehn Jahre als Quarantäneartz, 297. 
gönderilmesini ister. Zira, halihazırda postalar, dezenfeksiyon işlemi için Yafa'ya veya Beyrut'a gönderilmekte ve bu da zaman kaybına sebep olmaktadır. Konsolos Hardegg, önemi giderek artan Hayfa limanında dezenfeksiyon imkânına sahip olunursa hem zaman hem para tasarrufu yapılabileceğini vurgular. Ayrıca Hacıların en sık kullandığı limanın Hayfa olduğunu, 1911 için Hayfa üzerinden Mekke'ye gidecek hacı sayısının tahmini 5.000'i bulacağını belirtir. Bundan başka Hicaz demiryolu ile Beyrut-Şam üzerinden seyahat eden yaklaşık 35.000 kişinin daha Hayfa'dan geçmeleri beklenmektedir. Hardegg, insan trafiğinin bu kadar yoğun olmasının, Hayfa'da karantina önlemlerinin alınmasını zorunlu kıldığını ve bunun için dezenfeksiyon malzemelerinin acil gönderilmesi gerektiğini belirtir. ${ }^{33}$

\section{Tiberya'da Kolera}

Liman kenti Hayfa'nın 60 km doğusundaki küçük bir kasaba olan, çoğunluğu yoksul Yahudilerden oluşan yaklaşık 9.000 kişilik nüfusa sahip Tiberya' da, 1912 Aralık sonunda 21 'i ölümle sonuçlanan 50 kolera vakası rapor edilir. Sağlık altyapısı yetersiz olan Tiberya'da bu olay üzerine 5 günlük karantina ilan edilir. ${ }^{34}$ Sıkı karantina tedbirlerine rağmen Tiberya'dan gelen Yahudi bir kadının kolera yüzünden öldüğü haberi Hayfa' da endişeye yol açar. ${ }^{35} 21$ Ocak 1913 'te yeni bir vaka ile karşılaşılmadığı, dolayısıyla Tiberya'da uygulanan karantinaya son verildiği belirtilir. Resmi rakamlara göre, salgının ilk görüldüğ̈ günden 1913 Ocak sonuna kadar Tiberya'da 129 kişiden 68'i kolera yüzünden hayatını kaybetmiştir. ${ }^{36}$

\section{Halep'te Kolera}

Halep, liman kentlerine demir ve kara yolları ile bağlantılı ve insan trafiğinin yoğun olduğu bir kent olmasından dolayı bulaşıcı hastalıkların uğrak yeridir. 1911 Eylül başında Şam'dan gelen bir kişinin Halep pazarından aldığı balık ve meyveleri yedikten 5 gün sonra, 6 Eylül 1911 'de, koleradan hayatını kaybettiği rapor edilir. Bu haberin duyulması, kentte bir panik havasının doğmasına yol açar. ${ }^{37}$ Birkaç ay sonra, 23-25 Ocak 1912'de 5 kişi daha koleradan ölünce, sağlık komisyonu resmi olarak Halep’te karantina uygulamasının başlatıldığını açıklar. ${ }^{38}$ Mart ortalarına kadar uygulanan sıkı karantina tedbirlerine 16 Mart'ta son verilir. Ancak Halep vilayeti sınırlarındaki İskenderun ve Antakya'da kolera vakaları görülmüştür. 11 Nisan'da Antakya'da, 17 Mayıs'ta Halep'te, Haziran başında ise İskenderun'da yeni kolera vakaları rapor edilir. ${ }^{39} 1912$ Haziran başında İskenderun'da 2 kişi koleradan hayatını

33 Bericht von Löytved Hardegg, J.Nr. 2042, PAAA, Konstantinopel-408, Haifa, den 23 September 1911.

34 Bericht von Löytved Hardegg, J.Nr. 2678, PAAA, Konstantinopel-408, Haifa, den 13 Dezember 1912.

35 Bericht von Löytved Hardegg, J.Nr. 2744, PAAA, Konstantinopel-408, Haifa, den 23 Dezember 1912.

36 Bericht von Löytved Hardegg, J.Nr. 233, PAAA, Konstantinopel-408, Haifa, den 21 Januar 1913.

37 Bericht von Rössler, J.Nr. 1878, PAAA, Konstantinopel-408, Aleppo, den 9 September 1911.

38 Bericht von Rössler, J.Nr.158, PAAA, Konstantinopel-408, Aleppo, den 26 Januar 1912.

39 Bericht von Rössler, J.Nr: 833, PAAA, Konstantinopel-408, Aleppo, den 20 Mai 1912. 
kaybeder. ${ }^{40}$ İskenderun'da vakalar ve ölümler 1912 sonuna kadar hızla artar. ${ }^{41}$ Ancak Aralık 1912 ’de İskenderun'da kolera salgınının -şimdilik- sonlandığı rapor edilmiştir. ${ }^{42}$

\section{Beyrut ve Şam'da Kolera}

1912 sonlarında Halep civarında yeniden görülmeye başlayan salgın, kısa sürede güneye doğru yayılmıştır. Şam koleranın yoğun görüldüğü bir kent haline gelir. Şam ile sıkı ilişkisi olan Beyrut, 2 ölümle sonuçlanan kolera vakasından sonra önlemleri sıkılaştırma yoluna gider. Beyrut-Şam demir yolu seferleri durdurulur ve Şam' dan gelenlere 5 günlük karantinaya girme şartı getirilir. Bunu duyan Mısır, benzer bir karantinayı Beyrut’tan gelenlere karşı uygulama kararı alır. ${ }^{43}$

\section{Adana'da Kolera}

Bağdat demiryolu hattının önemli duraklarından biri olan Adana ve çevresinde de kolera salgını etkili olmuştur. Osmaniye-Toprakkale'de, Bağdat demiryolu şantiyesinde çalışanlardan günlük 3-4 işçinin koleradan öldüğü rapor edilir. Şantiyede görevli Alman mühendis Winkler, işçilerin paniğe kapılıp işi bırakmamaları için gittikçe artan ölüm oranlarının gizlendiğini ve gerçek rakamların açıklanmadığını düşünmektedir. Bağdat Demiryolu Şirketi yetkilisi Winkler, şantiyedeki ölümlerden sonra konuyu Adana valiliğine ileterek acil yardım talebinde bulunur. Adana valiliği elindeki kıt imkânlarla yardımcı olmaya çalışır. Ancak valiliğin bekçi olarak 2 jandarma göndermesi dışında etkili bir müdahalesi olamayınca Winkler, Adana Alman konsolosluğuna başvurarak yardım ister. Eldeki yetersiz imkanlarla şantiyede kurulan izolasyon çadırlarına alınan hasta işçiler, karantina kurallarını hiçe sayarak akşam karanlığında çadırları terk ederler. Bunun üzerine valiliğin görevlendirdiği 2 jandarma, çadırların önünde nöbet tutar. Mühendis Winkler, nöbet tutan iki jandarmanın firarları önlemekte ya yetersiz ya da isteksiz olduklarından şikâyet etmektedir. Firara teşebbüs edenlere karşı silah kullanmayı önermesine rağmen bu öneri askerler tarafından uygulanmaz. Diğer yandan sağlıklı işçiler, karantina önlemlerini ciddiye almaz ve hasta arkadaşlarını izolasyon çadırlarında ziyaret ederler. Winkler, Adana konsolosluğuna durumun vahim olduğunu, hemen önlem alınmazsa hastalığın hızla yayılacağını ve bütün ülkenin yeni bir salgın dalgasıyla karşılaşacağını açıklar. Zira hastalık taşıyan işçiler, şantiyeden ayrılarak civar illere, memleketlerine doğru (Maraş, Harput, Diyarbakır, Erzurum, Osmaniye, Adana...) yola koyulmuşlardır bile... ${ }^{44}$

40 Bericht von Rössler, J.Nr: 922, PAAA, Konstantinopel-408, Aleppo, den 8 Juni 1912.

41 Bericht von Bergfeld, J.Nr: 1780, PAAA, Konstantinopel-408, Aleppo, den 8 November 1912.

42 Bericht von Bergfeld, J.Nr: 1965, PAAA, Konstantinopel-408, Aleppo, den 6 Dezember 1912.

43 Bericht aus Beirut, J.Nr: 2836, PAAA, Konstantinopel-408, Beirut, den 12 September 1912.

44 Herr Oberingeneur Winkler, der Vorstand der II. Bauabteilung, "Cholera-Epidemie", Gesellschaft für den Bau von Eisenbahnen in der Türkei, Bau der Bagdadbahn Der Vorstand der Bauabteilung II, PAAA, Konstantinopel-408, Adana, den 16 Dezember 1911. 


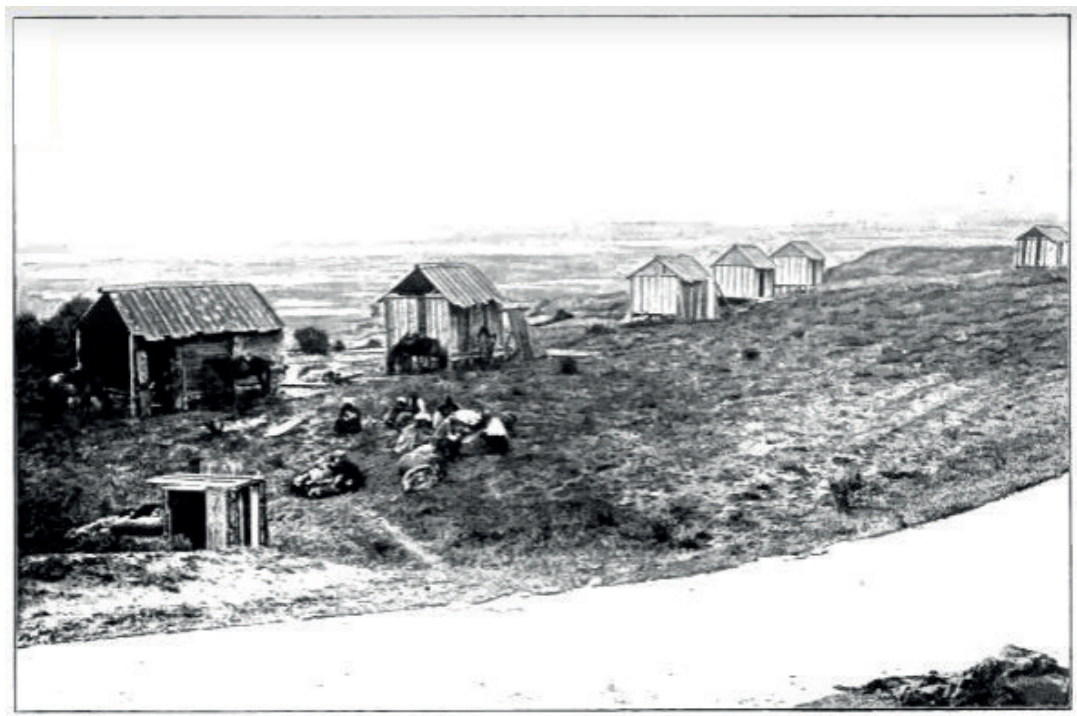

DIE QUARAHTAMEBARACKE FUR REISENDE IN BOZAMTI.

Adana-Pozantı' da karantina istasyonlar1 ${ }^{45}$

\section{Hanya'da (Girit) Kolera}

1911 Eylül'ünde Yafa'da kolera söylentilerinin yayıldığı günlerde Girit adasındaki Hanya kentinden kolera salgını haberi gelir. Yine bir gemi ile Hanya'ya gelen bir kadın yolcunun kolera belirtileri gösterdikten hemen sonra öldüğü bildirilir. Ancak İngiliz liman doktoru, hastalığa sıradan bir bağırsak rahatsızlı̆ğ teşhisini koyar. İstanbul'da faaliyet gösteren uluslararası sağlık komitesinin kararları, aslında böylesi durumlarda, ticaret ve yolcu gemilerini karantina uygulamaya zorunlu kılmaktadır. Buna rağmen Hanya limanında bu kurallar göz ardı edilir ve hiçbir önlem alınmadan gemilerin Girit’teki limanlara yanaşmasına izin verilir. Bu durum yerel halkta büyük bir huzursuzluk doğmasına yol açar. ${ }^{46}$

Yunanistan hükümeti benzer bir durumla karşılaşmamak için, Hanya limanında kadın yolcunun ölümüyle sonuçlanan bir kolera vakası görüldüğü duyumunun alınmasından hemen sonra, derhal Girit limanlarından gelen bütün gemilere 2 günlük karantina uygulanacağını duyurur. Yerel hükümetin karar almakta geç kaldığını düşünen Hanya halkı, çok sayıda Müslüman yolcunun kolera salgınından sakınmak amacıyla Selanik ve İzmir'den, Girit'e gelmek üzere oldukları bilgisi karşısında 5 Eylül'de acil bir toplantı düzenler. Toplantıdan -İstanbul'daki uluslararası sağlı komitesinden henüz bir karantina kararı çıkmamış olmasına 
rağmen -- Hanya, Kandiye ve Resmo limanlarında karantina istasyonları kurulması, hiçbir geminin karantinaya girmeden yolcu indirmesine izin verilmemesi, karantinayı reddederek gemiden inmekte 1srarcı olan yolcuların, gerekirse şiddet kullanarak engellenmesi kararı çıkar. Girit yerel hükümet başkanı Kunduros, yabancı devlet konsoloslarına Hanya halkının protestosuna müdahale etmeyeceğini bildirir. Bu tavrı, halkın kararına örtülü bir destek verdiğini göstermektedir. Bu karardan ilk etkileneler, bir İtalyan ve bir Avusturya gemisi olur. Trieste limanından gelen Avusturyalı Lloyd gemisinin yolcu indirmesine izin verilmez. Gemi kaptanı, sadece postasını teslim ederek limandan ayrılır. ${ }^{47}$ Bunun üzerine 4 garantör devlet, Birleşik Krallık, Fransa, İtalya ve Rusya konsolosları 10 Eylül'de yerel Girit hükümetine ortak bir nota gönderir ve Hanya halkını sağduyulu davranmaya davet eder. Kunduros başkanlığındaki yerel hükümet notaya verdiği cevapta, 1902'deki salgının yıkıcı sonuçlarını hatırlatır ve halkın haklı tepkisine karşı bir tavır almasının söz konusu olmadığını yineler. Benzer bir notayı Avusturya-Macaristan da vererek Girit hükümetine İstanbul'daki uluslararası sağlık komitesinin karantina yönünde bir kararı olmamasına rağmen, karantina tedbirlerinin yürürlüğe konmasını doğru bulmadığını, deniz trafiğini aksatacak eylemlerden kaçınılması gerektiğini bildirir. Başkan Konduros geri adım atmaz ve cevabında, kolera salgınının bulunduğu kentlerin limanlarından gelen gemilerin, 5 günlük karantina şartına uyduktan sonra Girit limanlarını kullanmalarına izin verileceğini belirttir. ${ }^{48}$

\section{İzmir'de Kolera}

İzmir, 1911'de koleranın en çok görüldüğü liman şehirlerinden biri haline gelir. Bir haftalık sürede (11-17 Eylül 1911) 30’u ölümle sonuçlanan 50 kolera vakası rapor edilir. Almanya’nın İzmir konsolosu, 11 Eylül öncesine ilişkin bir oran vermemekle beraber bu rakamın bir hafta önceki orana kıyasla çok az olduğunu belirterek kolera vakalarındaki ani düşüşe dikkat çekmiş, böylece önceki haftalarda yüzlerce ölümlü vakaya işaret etmiştir. Konsolos koleradan başka, bir bulaşıcı hastalık haberini daha rapor eder. Buna göre, Mersin limanından karantina altındaki İzmir-Klazomenai limanına gelen Amerikan bayraklı bir kıyı vapurunda, karantina kontrolü sırasında Alman posta memuruna veba tanısı konmuştur. Bubonik veba ${ }^{49}$ teşhisi konan hasta birkaç gün sonra (17 Eylül) hayatını kaybeder. Haberin duyulmasından sonra, zaten kolera ile boğuşan İzmir halkı büyük bir endişeye kapılır. Alman postası baştan sona dezenfekte edilir. Bu haber karşısında Dr. Aristidi Paşa (1862-1938) başkanlığındaki sağlık komitesi, sağlık tedbirlerini sıkılaştırma kararı alır. ${ }^{50}$ Yapılan resmî açıklamada ölen posta memurunun iş arkadaşına da veba bulaştırdığı açıklanır. 23 Eylül'de yapılan resmî açıklamada 17 kolera

47 Bericht von Krüger, J.Nr.285, PAAA, Konstantinopel-408, Canea, den 7 September 1911.

48 Bericht von Krüger, J.Nr. 298, PAAA, Konstantinopel-408, Canea, den 23 September 1911.

49 Bubonik veba (Hıyarcıklı veba) veba hastalığının en yaygın biçimidir. Hastalığa Yersinia pestis adı verilen enterobakteri neden olur. Bakteri vücuda girdikten sonra 3 ila 8 gün içinde etkisini gösterir. Belirtileri, yüksek ateş, üşüme duygusu, baş ağrısı, ishal ve bubo adı verilen lenf bezi şişmeleridir.

50 Bericht von Hueber, Jr. Nr, 2924, PAAA, Konstantinopel-408, Smyrna, den 18 September 1911. 
vakasının daha tespit edildiği, bu hastalardan 9'unun öldüğü ve gerekli tedbirlerin alınmaya devam ettiği açıklanır. ${ }^{51} 20$ Ekim'deki resmî açıklamada, İzmir' de birkaç haftadır yeni veba ve kolera vakalarının görülmediği, ancak Aydın'dan az da olsa birkaç kolera haberi geldiği, ayrıca Osmanlı'nın çeşitli bölgelerinde kolera haberlerinin gelmeye devam ettiği, dolayısıyla İzmir'de koleranın sonlandığını söylemek için erken olduğu belirtilir. ${ }^{52}$

Kolera 1913 yazında İzmir'de yeniden ortaya çıkar. Civar illerden ve Balkanlardan İzmir'e gelen 15 kişiye kolera teşhisi konmuştur. Balkan savaşı dolayısıyla yurtlarından sürülen insanların salgını tetikleyeceğine ve acil tedbir alınmasının gerekliliğine dikkat çekilir. ${ }^{53}$ Bunun üzerine İzmir'de karantina tedbirleri yeniden sıkılaştırılır. Salgının askerler arasında yayılmasından korkulduğundan, 19 Ocak 1914'te İzmir-Klazomenai limanına yanaşan Ittihad adlı gemideki 700 askere 5 günlük karantina uygulanır. ${ }^{54}$

\section{Selanik ve Çanakkale'de Kolera}

Koleranın 1911'de hızlı ilerleyişi ve kısa sürede onlarca insanın hayatını kaybetmesi karşısında, Selanik’te bir tür seferberlik başlatılır ve sıkı karantina tedbirlerine başvurulur. Ege denizinin önemli liman kenti Selanik’te kolerayla mücadele için sıhhiye müfettişi Tevfik Rüştü Bey başkanlığında toplantılar düzenlenir ve müdafaa heyetleri kurulması için bir komisyon oluşturulur. ${ }^{55}$ Salgın Selanik’te 1911 Ekim ayında durulur ve bir ay sonra son bulur. ${ }^{56}$ Ancak dış etkilere açık bir liman kenti olan Selanik, en ufak bir salgın şüphesinde tedbiri elden bırakmaz. Zira kolera söylentileri üzerine 1913 Mart sonunda, İskenderiye'den gelen yolcular için yolculuk süresinin dâhil olduğu 3 günlük karantina uygulanacağı duyurulur..$^{57}$

Ege ve Marmara denizini birbirine bağlayan Çanakkale'de 14 Ocak 1914'te kolera vakaları rapor edilir. Bazı askerlerin koleraya yakalanması, bütün bir garnizonun korkuya kapılmasına sebep olur. Hastalığa yakalanan üç asker, askeri hastanede tedavi altına alınır. Ancak tedavi sonuç vermez ve askerler birkaç gün içinde hayatlarını kaybederler. ${ }^{58}$ Hemen ardından Çanakkale'de de sıkı karantina tedbirleri uygulanır. İyi haber Şubat ayı ortasında gelir. Karantina tedbirlerinin uygulanmasından bu yana 14 gün geçmiş olmasına rağmen, henüz yeni bir kolera vakası kaydedilmeyince Çanakkale'de karantina uygulamasına son verildiği duyurulur. ${ }^{59}$

51 Bericht von Hueber, Jr. Nr, 2995, PAAA, Konstantinopel-408, Smyrna, den 25 September 1911.

52 Bericht von Hueber, Jr. Nr. 3370, PAAA, Konstantinopel-408, Smyrna, den 20 Oktober 1911.

53 Bericht von Hueber, Jr. Nr. 3158, PAAA, Konstantinopel-408, Smyrna, den 6 August 1913.

54 Informations Sanitaires, Movement des Troupes et des Émigrés, No:51, PAAA, Konstantinopel-408, Constantinople, le 20 janvier 1914.

55 Odabaşı, "Selanik 1910-1911," 58.

56 Odabaş1, "Selanik 1910-1911," 63.

57 Bericht aus Salonik, J.Nr. 1556, PAAA, Konstantinopel-408, Salonik, den 27 März 1913.

58 Informations Sanitaires, No: 40-42, PAAA, Konstantinopel-408, Dardanelles, le 15-16 Janvier 1914.

59 Bericht von Mertens, Bericht No: 66, J. Nr:1640, PAAA, Konstantinopel-408, Konstantinopel, den 16 Februar 1914. 


\section{Trabzon'da Kolera ve Veba}

Konsolosluk raporlarında yer alan tek salgın kolera değildir. 1913 sonbaharında Trabzon'da veba salgınının sonlandığını bildiren bir rapor, koleranın yanı sıra diğer salgın hastalıkların da kentleri tehdit ettiğini göstermektedir. Trabzon'da Ekim başında veba teşhisi konulan 12 kişiden 2'si hayatını kaybetmiştir. ${ }^{60}$ Veba tehdidi henüz sonlanmamışken, Ocak 1914 'te Trabzon'da koleraya yakalanan 7 kişiden 5 'inin hayatını kaybettiği bildirilir. Aslında salgından etkilenenlerin açıklanan rakamların çok üstünde olduğu ve hastalığın askerlerin arasında da yayıldığı bilindiği halde gerçek rakamların gizlendiği bildirilir. ${ }^{61}$ Söylentiler Trabzon'da hızla yayılır. Yetkililer, Trabzon ticaretinin bu haberlerden kötü etkilenmesinden çekindikleri için, uluslararası sağlık komitesinin bu tür durumlarda karantina uygulanmasını zorunlu tutan prensip kararına rağmen, karantina ilan etmezler. Alman konsolos Bergfeld, 1910'da yaşanan bölgesel salgını örnek göstererek, salgının 1914'e kadar sağlık koşullarında herhangi bir iyileşme görülmeyen Trabzon'da daha da hızlı yayılacağı uyarısını yapmıştır. Zira bölgenin nemli ve soğuk havası ile sağlık teşkilatının zayıf oluşunun, 1910'daki bölgesel salgının hızla yayılmasına hizmet etmiş olduğunu hatırlatır. ${ }^{62}$

\section{Sonuç}

Balkanlardan Kafkasya'ya ve Ortadoğu'ya kadar uzanan geniş bir coğrafyaya yayılan Osmanlı İmparatorluğu'nun kentlerinde koleranın ilk görüldüğü yer ve yol açtı̆̆ı kayıplara ilişkin tutulan istatistiklerin kesinliği tartışmaya açıktır. Zira hastalığın ilk olarak hangi kentte görüldüğü ve gerçekte kaç kişinin öldüğünü kesin bir dille iddia etmek, dönemin koşulları düşünüldüğünde oldukça güçtür. Birçok akademik çalışmada değişken ölüm oranları ve salgınlarla ilgili ortalama bilgilerin sunulması bu alanda kesin bir dille konuşmanın zorluğunu ortaya koymaktadır. Koleranın imparatorluğun en doğusunda görüldükten birkaç gün sonra en batısındaki bir liman kentinde ortaya çıkmış olması, aynı anda hem kara hem deniz yoluyla yayılan mikrobun birçok yerden giriş yapmış olabileceği ihtimalini doğurmaktadır. Ancak kesin olan şudur ki, kolera, 1911-1914 arasında imparatorluğun en ücra kentlerinde görüldüğü gibi, İstanbul, İzmir, Selanik, Hayfa, Hanya, Samsun, Trabzon gibi işlek limanlarda veya Şam, Halep, Adana gibi demiryoluna sahip görece büyük kentlerde görülmüş ve can kaybına yol açmıştır.

Osmanlı Devleti’nde hastalığın ilk kez görüldüğü 1831 tarihinden itibaren salgın karşısında alınacak önlemler görüşülmüş, ilgili sağlık komisyonları kurularak karantina uygulamasına geçilmiştir. Ancak hastalığın geniş bir coğrafyaya yayılması ve dönemin hijyen koşullarının hastalığın bulaşmasını engellemek için yetersiz olması karşısında çoğu zaman çaresiz

60 Bericht von Bergfeld, J.Nr. 509, PAAA, Konstantinopel-408, Trapezunt, den 11 Oktober 1913.

61 Bericht von Bergfeld, J.Nr. 32, PAAA, Konstantinopel-408, Trapezunt, den 12 Januar 1914.

62 Bericht von Bergfeld, J.Nr. 35, PAAA, Konstantinopel-408, Trapezunt, den 13 Januar 1914. 
kalınmış, salgının önüne geçilememiştir. Raporlardaki kayıtlar, yerel Osmanlı yöneticilerinin, yetersiz sağlık altyapısına rağmen, salgından korunmak için mevcut imkânlar dâhilinde tedbirler almaya çalıştıklarını ortaya koymaktadır. Ancak kimi kentlerde yerel halk, alınan önlemleri yetersiz bulunca inisiyatifi ele alarak, örneğin bulaşıcı hastalık taşıdığı varsayılan bir geminin yanaşmasına ve yolcu indirmesine şiddetle karşı çıkabilmiştir. Yöneticiler, bazı durumlarda yerel halkın paniğe kapılmasını ve kaotik bir ortamın doğmasını önlemek amacının yanı sıra, özellikle deniz ticaretinin ve trafiğinin aksayarak maddi kayıpların önüne geçmek adına salgın haberleri ile ilgili gerçekleri manipüle etmişler veya halktan gizlenmeye çalışmışlardır. Ayrıca Akdeniz'de deniz taşımacılığında rol üstlenen ülkelerin konsoloslukları da devreye girerek deniz trafiğini aksatacak adımların atılmasını engellemeye çalışmışlardır. Bu çerçevede Yafa ve Hanya'da olduğu gibi kimi zaman kolerayı görmezden gelerek, yolcu ve yük gemilerinin rutin seferlerine devam etmeleri için lobi faaliyeti yürütmüşlerdir.

Salgın sırasında farklı kentlerde görev yapan Almanların, Almanya'dan dezenfeksiyon ve tıbbi malzemeleri sağlamaya çalıştıkları olmuştur. İlk görüldüğü andan itibaren, yerel halk paniğe kapılarak korku ve çaresizlik içerisinde hastalığı, ilahi bir yardım ile veya tıbbi önlemlerle yenmeyi ummuştur. Bitti sanılırken, başka bir kentten gelen yeni bir vaka haberi halkı ve hükümet yetkililerini paniğe sürüklemeye devam etmiştir. Aynı dönemde kolera gibi tehlikeli diğer bir bulaşıcı hastalık olan vebanın da halk sağlığını tehdit etmeye devam ettiği anlaşılmaktadır.

Y1llarca devam eden kolera, bazen aylarca süren karantina uygulamalarına rağmen, mevcut imkânların yetersizliği yüzünden tamamıyla sonlandırılamamış, insan kayıplarının önüne geçilememiştir. $\mathrm{Bu}$ durum yolcu ve posta taşıyan gemilerin seferlerinin aksamasına bağlı olarak ticari kayıplara da yol açmıştır. Karantina kuralları sıkı uygulandı̆̆ı halde, hastalığın bulaştığı kimi insanların gizlice karantina çadırlarını terk ettiği veya sağlıklı insanların girmeleri yasak olan karantina çadırlarında yatan hastaları ziyaret ettiği olmuştur. Kısıtlamalara ve kimi zaman polisiye önlemlere rağmen, bazı sorumsuz insanlar yasakları dikkate almayarak veya bilinçsizce kuralları önemsemeyerek, bir kentten diğerine yolculuk yapmışlar, böylece hastalığın daha hızlı yayılmasına hizmet etmişlerdir. Salgının karşısında alınması gereken önlemleri dikkatte almayan bu tür sorumsuz davranışların, aradan bir yüzyılı aşkın bir zaman geçmesine rağmen, COVID-19 salgınının günlük yaşamı felç ettiği 2020'li yılların dünyasında hâlâ yaşanıyor olması düşündürücüdür.

Yirminci yüzyılın başlarında sürgün ve savaşlarla yaşanan büyük insan kayıplarına, kolera, grip veya veba gibi diğer bulaşıcı hastalıklardan ölenler de eklenmiş, salgın dönemlerinde adeta bir insanlık dramı yaşanmıştır. Osmanlı coğrafyasında 1910'da şiddetlenen kolera salgını, bütün önlemlere, beklentilere ve dualara rağmen hızla yayılmış, yıllarca devam etmiş, Balkan ve I. Dünya savaşları süresince mültecilerin ve askerlerin arasında gizli bir düşman gibi can almaya devam etmiştir. 
Hakem Değerlendirmesi: Dış bağımsız.

Çıkar Çatışması: Yazar çıkar çatışması bildirmemiştir.

Finansal Destek: Yazar bu çalışma için finansal destek almadığını beyan etmiştir.

Peer-review: Externally peer-reviewed.

Conflict of Interest: The author has no conflict of interest to declare.

Grant Support: The author declared that this study has received no financial support.

\section{KAYNAKÇA / BIBLIOGRAPHY}

\section{Arşiv Kaynakları / Archival Sources}

Politische Archiv des Auswärtiges Amt, Bundesrepublik Deutschland, Berlin

Bericht aus Beirut, J.Nr: 2836, PAAA, Konstantinopel-408, Beirut, den 12 September 1912.

Bericht aus Salonik, J.Nr. 1556, PAAA, Konstantinopel-408, Salonik, den 27 März 1913.

Bericht von Bergfeld, J.Nr. 32, PAAA, Konstantinopel-408, Trapezunt, den 12 Januar 1914.

Bericht von Bergfeld, J.Nr. 35, PAAA, Konstantinopel-408, Trapezunt, den 13 Januar 1914.

Bericht von Bergfeld, J.Nr. 509, PAAA, Konstantinopel-408, Trapezunt, den 11 Oktober 1913.

Bericht von Bergfeld, J.Nr: 1780, PAAA, Konstantinopel-408, Aleppo, den 8 November 1912.

Bericht von Bergfeld, J.Nr: 1965, PAAA, Konstantinopel-408, Aleppo, den 6 Dezember 1912.

Bericht von Dr. Brode, J.Nr.1166, Konstantinopel-408, Jaffa, den 8 September 1911.

Bericht von Dr. Brode, J.Nr.1171, PAAA, Konstantinopel-408, Jaffa, den 11 September 1911.

Bericht von Dr. Brode, J.Nr.1570, Konstantinopel-408, Jaffa, den 29 November 1911.

Bericht von Hueber, Jr. Nr, 2924, PAAA, Konstantinopel-408, Smyrna, den 18 September 1911.

Bericht von Hueber, Jr. Nr, 2995, PAAA, Konstantinopel-408, Smyrna, den 25 September 1911.

Bericht von Hueber, Jr. Nr. 3158, PAAA, Konstantinopel-408, Smyrna, den 6 August 1913.

Bericht von Hueber, Jr. Nr. 3370, PAAA, Konstantinopel-408, Smyrna, den 20 Oktober 1911.

Bericht von Krüger, J.Nr. 298, PAAA, Konstantinopel-408, Canea, den 23 September 1911.

Bericht von Krüger, J.Nr.285, PAAA, Konstantinopel-408, Canea, den 7 September 1911.

Bericht von Krüger, J.Nr.294, PAAA, Konstantinopel-408, Canea, den 11 September 1911.

Bericht von Löytved Hardegg, J.Nr. 2042, PAAA, Konstantinopel-408, Haifa, den 23 September 1911.

Bericht von Löytved Hardegg, J.Nr. 233, PAAA, Konstantinopel-408, Haifa, den 21 Januar 1913.

Bericht von Löytved Hardegg, J.Nr. 2678, PAAA, Konstantinopel-408, Haifa, den 13 Dezember 1912.

Bericht von Löytved Hardegg, J.Nr. 2744, PAAA, Konstantinopel-408, Haifa, den 23 Dezember 1912.

Bericht von Mertens, Bericht No: 66, J. Nr:1640, PAAA, Konstantinopel-408, Konstantinopel, den 16 Februar 1914.

Bericht von Rössler, J.Nr. 1878, PAAA, Konstantinopel-408, Aleppo, den 9 September 1911.

Bericht von Rössler, J.Nr.158, PAAA, Konstantinopel-408, Aleppo, den 26 Januar 1912.

Bericht von Rössler, J.Nr: 833, PAAA, Konstantinopel-408, Aleppo, den 20 Mai 1912. 
Bericht von Rössler, J.Nr: 922, PAAA, Konstantinopel-408, Aleppo, den 8 Juni 1912.

Herr Oberingeneur Winkler, der Vorstand der II. Bauabteilung, "Cholera-Epidemie”, Gesellschaft für den Bau von Eisenbahnen in der Türkei, Bau der Bagdadbahn Der Vorstand der Bauabteilung II, PAAA, Konstantinopel-408, Adana, den 16 Dezember 1911.

Informastions Sanitaires, No:40-42, PAAA, Konstantinopel-408, Dardanelles, le 15-16 Janvier 1914.

Informations Sanitaires, Movement des Troupes et des Émigrés, No:51, PAAA, Konstantinopel-408, Constantinople, le 20 janvier 1914.

\section{Basılı Kaynaklar / Printed Sources}

Barua, Dhiman. "History of Cholera," Cholera, yayına hazırlayanlar Dhiman Barua ve William B. Greenough III içinde, 2-15. New York: Plenum Medical Book Company, 1992.

Childs, William John. Yürüyerek Anadolu, Samsun-Halep, 1911-1912. Çeviren Füsun Tayanç ve Tunç Tayanç. İstanbul: Kitap Yayınevi, 2017.

Çalık, Ramazan ve Muzaffer Tepekaya, "Birinci Dünya Savaşı Esnasında Anadolu'daki Salgın Hastalıklar ve Ermeniler.” Selçuk Üniversitesi Sosyal Bilimler Enstitüsü Dergisi Sayı 16 (2006): 205-228.

Emgili, Fahriye. "Cumhuriyet Dönemi Nüfus Siyasetinde Sitma Mücadelesinin Önemi.” The Journal of Academic Social Science Studies Say1 50 (2016): 297-318.

Karaimamoğlu, Tolga. "Kara Ölüm Veba Salgını ve Ortaçă̆ İngiltere’sine Etkileri.” Akademik Sosyal Araştırmalar Dergisi 4, 37 (2016): 591-610.

Kuneralp, Sinan. “Osmanlı Yönetimindeki (1831-1911) Hicaz'da Hac ve Kolera.” Çeviren Münir Atalar, Ankara Üniversitesi Osmanlı Tarihi Araştırma ve Uygulama Merkezi Dergisi Say1 7 (1996): 497-511.

Odabaşı, İ. Arda. "Selanik 1910-1911: Kolera Salgınları, Kahraman Bir Doktor, Yahudi İşçilerin İsyanı ve Serseri Gazeteciler.” Toplumsal Tarih Sayı 296 (Ağustos 2018): 56-63.

Özdemir, Hikmet. Salgın Hastalıklardan Ölümler 1914-1918. Ankara: Türk Tarih Kurumu, 2005.

Saad, Lamec. Sechzehn Jahre als Quarantäneartz in der Türkei. Berlin: Dietrich Reimer (Ernst Vohsen), 1913. Sarıyıldız, Gülden. Hicaz Karantina Teşkilatı. Ankara: Türk Tarih Kurumu, 1996.

Yıldırım, Nuran. “İstanbul Boğazı’nda Karantina Uygulamaları.” Yeni Deniz Mecmuası (1 Mart 2016): 45-61. Yıldırım, Nuran. "Kolera ve İstanbul Suları.” Toplumsal Tarih Sayı 145 (Ocak 2006): 2-11.

Yıldırım, Nuran. “Osmanlı Coğrafyasında Karantina Uygulamaları. Karantina istemezük!” Toplumsal Tarih Say1 150 (Haziran 2006): 18-27.

Yıldırım, Nuran. “Tanzimat'tan Cumhuriyet'e Koruyucu Sağlık Uygulamaları.” Tanzimat'tan Cumhuriyet'e Türkiye Ansiklopedisi, 5: 1320-1338. İstanbul: İletişim Yayınları, 1985.

Yıldız, Emrah. “Arşiv Belgeleri Işı̆̆ında Mersin’de Salgın Hastalıklar (19. Yüzyıl).” Mersin Üniversitesi Akdeniz Kent Araştırmaları Merkezi, yayına hazırlayanlar Tülin Selvi Ünlü ve Züheyla Sara Belge içinde 81-91. Mersin: Mersin Üniversitesi, 2013.

\section{Elektronik Kaynaklar /Electronic Sources}

Schulze-Tanielian, Melanie, Disease and Public Health (Ottoman Empire/Middle East). Erişim tarihi: 9.6.20 < https:// encyclopedia.1914-1918-online.net/article/disease_and_public_health_ottoman_empiremiddle_east> 
